\title{
Revitalisasi Nilai-nilai Pendidikan Agama Islam Dalam Menanggulangi Problematika Bullying Di Pesantren
}

\author{
Jannatul Firdaus, Nur Aisyah \\ Program Studi PAI, Universitas Nurul Jadid, Jawa Timur, Indonesia \\ Email corresponding author: 1akivazoro0069@gmail.com/nuraisyah_84@ymail.com
}

\begin{abstract}
ABSTRAK
Jenis Dewasa ini, pendidikan di Indoneia cenderung mendahulukan penguasaan aspek keilmuan dan kecerdasan, akan tetapi sering mengabaikan perilaku dan akhlak anak didik. Pengetahuan tentang akhlak moral yang didapatkan dalam pendidikan agama islam di sekolah atau di pesantren saat ini semakin diketepikan. Sebagian orang mulai tidak memperhatikan lagi bahwa pendidikan agama islam tersebut berdampak pada perilaku seseorang. Contohnya, Maraknya perilaku bullying atau perundungan yang terjadi disekolah bahkan mulai banyak terjadi di pesantren mulai dihawatirkan oleh banyak pihak terutama orang tua dan para pendidik. hal tersebut karena pesantren harusnya menjadi tempat utama dalam pembentukan karakter dan akhlak para penerus bangsa. Tujuan penelitian ini mengidentifikasi penggiatan kembali nilai-nilai pendidikan agama islam dalam mengatasi masalah bulliying di pesantren. Memandang Pesantren diasosiasikan dengan lembaga pendidikan yang mengajarkan nilai-nilai kebajikan, perilaku positif, dan muatan religiusitas yang kuat, maka dari itu dikhawatirkan masalah bulliying berdampak negatif pada perkembangan mental dan moral para santri.
\end{abstract}

Keyword: Nilai-nilai pendidikan agama islam, bulliying, pesantren

\section{PENDAHULUAN}

\section{Latar Belakang Masalah}

Pendidikan islam bukan hanya dimengerti sebatas "pelajaran agama", namun juga berimplikasi luas pada seluruh aspek menyangkut agama islam, untuk melahirkan pribadi-pribadi islami yang mampu mengembangkan misi yang diberikan oleh Allah, yakni sebagai khalifah yang ditugaskan untuk menyembah Allah, melaksanakan segala perintah-Nya, dan menjauhi segala larangn-Nya. Ali Ashraf menyebutkan, "The ultimate aim of muslim education lies in the realization of complete submission to Allah on the level of the individual, the community and humanity at large" (tujuan tertinggi dari pendidikan islam adalah merealisasikan kepasrahan penuh pada Allah pada tingkat individual, komunitas dan umat).

Tujuan pendidikan islam yang utama ialah untuk melaksanakan perintah Allah. Oleh karena itu dapat kita pahami bahwa pendidikan islam dalam Ajaran 
Agama Islam berperanan penting dalam upaya mewujudkan manusia yang berakhlak mulia. Seperti sabda Nabi Muhammad SAW; "Orang mukmin yang paling sempurna imannya adalah yang paling baik akhlaknya." (Riwayat Abu Dawud No. 4682 di Kitaabus Sunnah dan Tirmidzi No. 1162 di Kitaabur Radhaa') Demikian Juga dalam sabda Rasullullah yang lain "Tidaklah Aku diutus melainkan untuk menyempurnakan akhlak manusia." Menurut hadist di atas dijelaskan bahwa agama islam menjujung tinggi akhlak dan moralitas umatnya.

Dewasa ini, tantangan Pendidikan Agama Islam khususnya di negara Indonesia adalah bagaimana mengimplementasikan nilai-nilai agama Islam kepada peserta didik secara utuh dan kaffah yang tidak saja menguasai pengetahuan, akan tetapi mempunyai kualitas iman, dan akhlak mulia. Hal tersebut dikarenakan tujuan dari pendidikan Islam adalah membentuk manusia yang mempunyai kepribadian yang serasi dan seimbang; tidak saja dalam bidang agama dan keilmuan, melainkan juga keterampilan dan akhlak. Al-Abrasyi menjelaskan bahwa aspek pendidikan akhlak sebagai tujuan pendidikan Agama Islam dan merupakan kunci utama bagi keberhasilan manusia dalam menjalankan tugas kehidupan.

Indonesia saat ini, khususnya di pesantren dimarakkan dengan perilaku remaja yang kurang berakhlak, yang mana perilaku tersebut bukan hanya berdampak pada dirinya, tetapi, juga kepada orang lain. Hal tersebut bisa dilihat dengan banyaknya kasus bulliying sebagai salah satu kasus remaja yang semakin parah dari waktu kewaktu. Terbukti, Menurut data Komisi Perlindungan Anak Indonesia (KPAI), sejak tahun 2011 hingga 2016 ditemukan sekitar 253 kasus bullying, terdiri dari 122 anak yang menjadi korban dan 131 anak menjadi pelaku. Menurut UndangUndang Perlindungan Anak pasal 12-18 nomer 23 tahun 2002, perlakuan yang harus dilindungi dari anak adalah diskriminasi, ekploitasi, penelantaran, kekejaman, kekerasan dan penganiayaan, ketidakadilan, dan perlakuan salah lainnya. Seharusnya anak-anak dapat merasakan Undang-Undang Perlindungan Anak yang tertuang dalam Kesejahteraan Anak.

Komisioner Komisi Perlindungan Anak Indonesia (KPAI) Retno Listyarti menilai sepanjang 2017-2019, kasus kekerasan anak yang terjadi di pondok pesantren cukup tinggi, meski tidak seluruhnya dilaporkan kepada KPAI. Namun hingga saat ini penyelesaian kasus-kasus yang terjadi sangat minim. "Kerap kali ketika terjadi kekerasan kepada santri, kiai hanya memanggil orang tua yang marah anaknya mendapatkan kekerasan, kemudian diberikan air putih dengan doa, kemudian masalah selesai, bahkan mereka mencabut laporannya dari kami," ujar dia kepada Republika.co.id, Selasa (14/1). Menurut Retno, pihak mereka tidak bisa melakukan apa-apa karena tidak ada regulasi yang mendukung mereka untuk memproses masalah tersebut. Bahkan akses masuk ke_pondok pesantren untuk penanganan pun mereka mengalami kesulitan.

Masa remaja awal seorang anak bukan hanya mengalami ketidakstabilan perasaan dan emosi, dalam waktu bersamaan mereka mengalami masa krisis. Krisis 
dalam konteks ini ialah krisis moral, yang menjadi momok ketakutan terbesar bagi pendidik, oleh karena itu pendidik tidak hanya bertugas mengajar melainkan juga membimbing moral dan akhlak para santri di pesantren maupun lingkungan sekitar. Hal tersebut kerana, yang akan menentukan nasib bangsa ke depan adalah santrisantri yang ada di pesantren. Dalam membina moral guru harus memiliki bermacam upaya dan strategi, untuk membentuk dan mengembangkan akhlak santri agar tidak terjadinya kasus bully, salah satunya memiliki pendekatan yang tepat untuk diterapkan di pesantren agar mampu membimbing akhlak santri sesuai yang diinginkan, guna menciptakan akhlak santri ke depan menjadi lebih baik.

Pelaku bullying kemungkinan besar juga sebatas mengulangi apa yang pernah ia lihat dan yang ia alami sendiri. Ia menganiaya anak lain karena mungkin ia sendiri dianiaya orang tuanya di rumah. Ia juga mungkin pernah ditindas dan dianiaya anak lain yang Iebih kuat darinya di masa Ialu. Perilaku buliiying yang terjadi dilingkungan pesantren ialah meliputi kekerasan fisik, tetapi lebih sering berbentuk ejekan, pengucilan, pemalakan, dan juga memerintah secara paksa atas nama seneoritas. Hal tersebut mungkin terjadi akibat santri yang berasal dari daerah yang memiliki adat dan budaya yang berbeda. Selain itu kurangnya pengawasan dari pengurus dan wali asuh serta banyaknya peraturan yang harus dipatuhi di pesantren juga menjadi salah satu sebab maraknya kasus bulliying yang terjadi di peantren. Oleh itu, nilai-nilai agama islam harus digiatkan kembali dan ditanamkan kembali pada diri setiap santri.

Beberapa penelitian juga menunjukkan bahwa korban bullying pada 4 tahun berikutnya berpotensi menjadi pelaku memandang ketika ini saja sudah banyak terjadi dikalangan remaja. Sedangkan para pelaku bullying, mereka beresiko tinggi terlibat kenakalan dan masalah criminal serius. Tidak hanya sampai disitu, bullying juga meresahkan orang tua dan masyarakat ketika terjadi di sekolah juga menyebabkan tingkat kepercayaan mereka pada institusi pendidikan menurun. Sejak tahun 1970-an, bullying telah dikenal sebagai penyakit social di beberapa Negara. Hal ini merupakan sebagian dampak dari bebcrapa penelitian yang secara sistematis telah dilakukan tahun 1970- dan dimulai dengan penelitian Olweus di Scandinavia $(1978,1993)$, dan berlanjut di Eropa, Amerika, Australia, Jepang.

Di Jepang, kekerasan ini dikenal dengan dime, menyeruak pada tahun 1984 ditandai dengan 16 peristiwa bunuh diri yang terkait dengan bullying. Di Amerika Serikat, meskipun bullying sangat popular, namun tidak mendapatkan perhatian sebesar di Jepang, karena terkacaukan dengan beragam bentuk kekerasan lain di sekolah yang juga marak terjadi. Suatu penelitian yang dilakukan pada sejumlah 4092 siswa usia 10-12 tahun di 20 sekolah menengah pertama di Portugal memberikan gambaran bahwa resiko tinggi menjadi korban bullying mengarah pada lakilaki dari kelas sosial ekonomi bawah. Sementara itu penelitian terhadap 238 siswa kelas tujuh Taiwan bahwa Sebagian responden telah menjadi korban bullying sejak pertama kali masuk sekolah menengah pertama. Aksi verbal dan fisik merupakan tipe kekerasan yang paling sering ditemui. Penelitian dengan self dan peer-report measure ini juga 
menunjukkan bahwa siswa laki-laki lebih banyak terlibat dalam kasus bullying fisik dan verbal daripada siswa perempuan.

\section{TINJAUAN PUSTAKA}

\section{Teori Thornoton (2010)}

Dalam teori Thornoton (2010) mengatakan bahwa bentuk perilaku tersebut dikatakan sebagai salah satu delenkuensi (kenakalan Anak), karena melanggar norma masyarakat dan dapat dikenai hukuman oleh lembaga hukum. Perilaku bullying disebabkan oleh sejumlah faktor, seperti keluarga (broken home) atau pola didik keras dan berlebihan), dan lingkungan bermain dan sekolah hingga media massa

\section{Teori Olweus (1993)}

Teori Olweus (1993) mendefinisikan bully yang mengandung tiga unsur mendasar dari perilaku bully sebagai berikut: bersifat menyerang (agresif) atau negatif, dilakukan secara berkali-kali dan adanya ketidak seimbangan kekuatan antara pihak yang terlibat. Kemudian Olweus mengdefinisikan dua subtype bully yaitu perilaku secara langsung (direct bully), misalnya penyerangan secara fisik dan perilaku secara langsung (indirect bully), misalnya pengucilan secara social. Riset menunjukkan bahwa bentuk bully tidak langsung, seperti pengucilan secara social, lebih sering digunakan oleh perempuan dari pada laki-laki. Sementara anak laki-laki menggunakan atau menjadi korban tipe bully secara langsung, misalnya penyerangan secara fisik.

\section{Teori Rigbi}

Teori Rigbi (2006) mendefinisikan bullying merupakan sebuah hasrat untuk menyakiti. Hasrat ini diperlihatkan ke dalam aksi, menyebabkan seseorang menderita, Aksi ini dilakukan secara Iangsung oleh seseorang atau kelompok yang Iebih kuat, tidak bertanggung jawab, biasanya berulang, dan dilakukan dengan perasaan senang.

\section{Hipotesis Penelitian}

Hipotesis 1: Bulliying berpengaruh negatif terhadap akhlak santri di pesantren.

Hipotesis 2 : Bulliying berpengaruh negatif terhadap emosional santri di pesantren Hipotesis 3: Bulliying berpengaruh negatif terhadap motivasi belajar santri dan mengebabkan semangat untuk belajarnya menurun.

Hipotesis 4: Bulliying berpengaruh negatif terhadap diri santri dikarenakan mengalami rasa takut tinggal dilingkungan pesantren.

Hipotesis 5: Bulliying berpengaruh terhadap psikolgi santri hingga menyebabkan trauma berpanjangan akibat kekerasan yang dialaminya. 
Hipotesis 6 : Santri yang mengalami bulliying cenderung pendiam dan mengurung diri serta tidak mau bersosialisasi dengan orang disekitarnya atau mungkin akan memutuskan untuk pindah pondok .

Hipotesis 7 : Penggiatan kembali nilai-nilai agama islam dapat mengatasi masalah bulliying di pesantren.

Hipotesis 8 : Penerapan materi agama islam pada santri dapat mencegah sekaligus mengatasi masalah bulliying di pesantren.

Hipotesis 9: Contoh tauladan dari senior khususnya para pendidik penting untuk menjadi tolak ukur dan pedoman para santri seterusnya .

Hipotesis 10 :Peran semua pihak terutama pendidik sangat penting dalam menanamkan nilai-nilai agama islam secara praktek hingga dapat di terapkan oleh para santri untuk mencegah masalah bulliying semakin merebak.

\section{METODE PENELITIAN}

\section{Metode Penelitian}

Adapun dalam hal ini metode pada penelitian ini adalah Penelitian pendekatan kualitatif. Dalam melakukan penelitian ilmiah harus dilakukan teknik penyusunan yang sistematis untuk memudahkan langkah-langkah yang akan diambil. Begitu pula yang dilakukan penulis dalam penelitian ini, yaitu dengan melakukan studi literatur pada beberapa jurnal yang membahas tentang niali-nilai pendidikan agama islam yang berkaitan dengan bulliying. Data yang didapat dari studi literatur ini akan digunakan sebagai acuan untuk membuat kueisioner penelitian. Karena metode literatur ini merupakan salah satu metode pengumpulan data yang difungsikan dalam metodologi penelitian sosial untuk mengusut data historis.

Dalam penelitian ini, beberapa informan telah dijadikan subjek penelitian. Informan merupakan orang atau narasumber tempat bertanya, dan juga orang yang bisa memberika informasi sebanya-banyaknya dalam penelitian ini. Dalam penelitian ini, peneliti wawancara kepada beberapa pendidik di pesantren yaitu para ustad dan ustadzah serta pendidik di luar pesantren untuk mengkaji nilai-nilai pendidikan agama islam apakah yang akan di berikan kepada santri untuk mencegah sekaligus menanggulangi problematika bulliying di pesantren. peneliti juga mewawancara para guru BK untuk melihat kembali kasus-kasus bulliying yang mungkin pernah terjadi sebelumnya, untuk dijadikan hipotesis awal dalam penelitian tersebut.

\section{HASIL PENELITIAN DAN PEMBAHASAN}

\section{Prilaku Bulliying di Pesantren}

Berdasarkan Hasil penelitian ini akan menghasilkan beberapa pembahasan terkait bulliying di pesantren baik santri putri mahupun santri putra yang mana telah 
menimbulkan beberapa persoalan terkait akhlaqul karimah santri di pondok pesantren. Hal pertama adalah bulliying seperti apa yang terjadi dikalangan santri di pondok, yang kedua adalah penggiatan kembali nilai-nilai pendidikan agama islam dalam mengatasi masalah bulliying di pesantren dan yang terakhir adalah strategi pendidik (pengurus, wali asuh dan Muallimat) dalam mengatasi terjadinya bulliying di kalangan santri.

Menurut penelitian dari Nugroho dan Fardhana , 2018 menemukan bahwa 59\% siswa-siswi pesantren mengaku menerima perlakuan bullying dari temannya. Penelitian lain yang dilakukan dalam konteks pesantren antara lain penelitian Yani, Winarni, \& Lestari, 2016. Penelitian ini dilakukan di salah satu pesantren di Jombang. Penelitian ini bertujuan untuk menggali pengalaman santri yang menjadi korban bullying di pesantren, mengeksplorasi perasaan santri saat menjadi korban bullying di pesantren. Dalam penelitian ini ditemukan terdapat tujuh tema yaitu pertentangan menganggu, mendapat perilaku yang menyakitkan dari senior, merasa tertekan, kehilangan motivasi, berusaha mengamankan diri, mencari pertolongan dan tidak menyelesaikan masalah.

Penelitian tentang bulliying di pesantren juga dilakukan oleh Marthunis \& Authar, 2017 bertujuan untuk mengetahui persepsi dan intervensi para guru di lingkungan di pesantren modern terhadap bullying. Hasil dari penelitian ini menemukan bahwa guru di pesantren menganggap bullying sebagai perilaku berbahaya yang perlu ditangani. Para guru di pesantren menggunakan beberapa intervensi dalam bentuk pendekatan reaktif daripada proaktif.

Terdapat kasus bulliying yang terjadi di salah satu pondok pesantren pada tahun 2016, yang berujung meninggalnya seorang santri. Para pelaku membawa korban yang masih duduk di bangku SMP ke dalam sebuah kamar dan mematikan lampunya. Didalam kamar tersebut korban dihajar beramai-ramai hingga pukul 23.00 WIB. Setelah itu dilarikan ke rumah sakit. Dan keesokan harinya korban meninggal dunia (Sindonew.com, 2016).

Berdasarkan studi pendahuluan yang dilakukan oleh seorang peneliti pada tanggal 6 Februari 2016 disalah satu lingkungan pesantren Jombang diperoleh data bahwa kejadian bullying terjadi pada siswanya. Pesantren merupakan lingkungan yang mempunyai rutinitas kegiatan antara senior dan junior. Selain itu karakteristik lingkungan pesantren yang memiliki jumlah santri yang cukup banyak. Santri datang dari berbagai daerah yang memiliki perbedaan latar belakang budaya. Jumlah pembina santri dengan banyaknya santri yang tinggal di pesantren tidak seimbang. Letak bangunan komplek antara santri lama dengan yang baru tidak dipisahkan.

Nashiruddin di tahun 2019, meneliti fenomena bullying di salah satu pondok pesantren di daerah Kajen, Kabupaten Pekalongan. Dalam penelitiannya, Nashiruddin menemukan perilaku bullying yang terjadi berbentuk verbal dan fisik. Secara verbal diantaranya dengan umpatan, meledek, membentak, membuat labellabel negatif, Secara fisik, diantaranya memukul, menendang, merusak barang 
temannya, memaksakan kehendak. Pada aspek dinamika psikologis korban bullying, kebanyakan mereka berada di jenjang sekolah yang lebih rendah (adik kelas) dan juga memiliki kekuatan fisik yang lebih lemah dari pada pelaku. Sementara itu, dinamika psikologis pelaku bullying menganggap diri mereka lebih unggul secara dan senang menonton film kekerasan (agresif). Kemudian, untuk dinamika psikologis dalam konteks situasi, pembina kurang responsif dalam mengatasi bullying dan di pesantren tidak ada pemisahan pondok (asrama) bagi santri senior dan junior.

Penelitian mengenai fenomena bullying di pesantren juga dilakukan oleh Yuhbaba pada tahun 2019 di Jember. Hasil penelitiannya menunjukkan bahwa pelaku bullying di pesantren adalah santri senior dan juga teman sebaya. Perilaku bullying in terjadi karena adanya persaingan, keinginan untuk diakui, iseng, dan kurangnya perhatian dari pembina pesantren. Meskipun pihak pesantren sudah melarang perilaku bullying di pesantren dan memberikan sangsi bagi pelaku, namun korban merasa takut untuk melaporkan kejadian bullying. Maka, hal tersebut pun luput dari pengawasan pihak pesantren. Dampak yang dirasakan korban bullying berupa luka secara fisik, perasaan tidak nyaman, sedih, ketakutan, cemas, hingga berkeinginan untuk berhenti atau keluar dari pesantren.

Santri yang tinggal di pesantren tidak semua atas keinginan pribadi melainkan karena paksaan dari orang tua. Sehingga tidak dapat diungkiri bahwa sebab-sebab di atas menjadi salah satu hal ini yang menjadi pemicu terjadinya bullying. Korban bullying mengaku bahwa ada rasa ketakutan, terancam, merasa tidak aman, sehingga hal ini mempengaruhi mental siswa selama berada di lingkungan tersebut. Dampak lanjut dari kejadian bullying pada siswa tidak mau masuk sekolah dan memutuskan untuk tidak melanjutkan sekolah.

\section{Temuan dan Pembahasan}

Berdasarkan hasil pengujian dalam penelitian ini dapat diketahui bahwa Penggiatan kembali nilai-nilai agama untuk mengatasi masalah bulliying sangatlah diperlukan supaya masalah tersebut tidak terus merebak. Dan demi mewujudkan keektifitasannya, perlulah kerjasama antara tenaga pendidik dan pengurus yang berkaitan. Aspek nilai PAI yang dimaksud yaitu aspek nilai-nilai akidah, ibadah, dan akhlak. Penanaman nilai-nilai tersebut secara normatif dilakukan pada berlangsungnya pelajaran PAI yang meliputi Akidah, Akhlak, Fiqih, serta Qur'an dan Hadits. Selain itu, penanaman nilai-nilai tersebut juga perlu diaplikasikan di setiap pembelajaran di setiap harinya, tidak hanya pada saat pembelajaran PAI saja.

Nilai-nilai PAI, seperti Religiutas (yakni pendalaman nilai-nilai agama dalam diri seseorang. Misalkan memperkenalkan anak melalui kebiasaan selalu mengingat Allah dimanapun ia berada, berdo'a setiap akan memulai kegiatan dan senantiasa bersyukur), Sosialisasi, (yaitu membiasakan anak hidup bersama, saling memperhatikan sesama, merasa saling membutuhkan, membiasakan berpikir jika bukan saya siapa lagi yang menolong mereka.), Gender (yaitu mengenalkan pada 
kesetaraan), Keadilan, (yaitu menjelaskan kepada anak bahwa akan mendapatkan hak dan kesempatan yang sama.), Demokratis, (yakni menghargai dan mengerahkan hasil imajinasi.), Kejujuran (membiasakan anak untuk menghargai orang lain dan menempatkan sesuatu sesuai dengan porsinya) bisa diterapkan di semua pondok pesantren dengan upaya dan metode dari kepala sekolah yang lebih banyak melibatkan guru PAI dan bekerjasama dengan guru-guru lainnya. Upaya yang dilakukan ialah selalu mensosialisasikan dan mengevaluasi perilaku siswa di pesantren. Aspek religiusitas dari anak sangat dibutuhkan sebagai pedoman hidupnya, yang nantinya intelektualitasnya akan mengikuti seiring pemahaman terhadap nilai-nilai PAI sudah tertanam pada diri santri. Kemudian meminta semua guru/ustad agar berusaha mengintegrasikan nilai-nilai PAI di setiap mata pelajaran.

Pendidikan agama ini diberikan bukan dengan cara mengajarkan dalil-dalil atau penjelasan tentang berbagai ajaran akhlak dalam agama, tetapi lebih kepada pentingnya penghayatan dan pengamalan dalam kehidupan sehar-hari, serta melibatkan para santri dalam dalam pembentukan akhlak dan karakter yang baik (Munthe). Pengamalan pembelajaran pendidikan Agama tergantung pada kondisi pesantren tersebut, sebagai contoh; Pondok Pesantren Nurul Ulum Malang (MTs Nurul Ulum Malang) pada saat pembelajaran Bahasa Indonesia, seorang guru mengawali proses pembelajaran pada pagi hari dengan mengucapkan salam dan memimpin siswa untuk membaca do'a akan belajar secara bersama. Kemudian guru memimpin untuk tadarus bersama yang kemudian menafsirkan kandungan ayat AlQur'an tersebut. Pembiasaan tersebut membantu siswa lebih mengerti akan makna yang terkandung didalam al-Quran. Dengan mentafsir ayat tersebut, guru dapat memberikan sebuah motivasi kepada siswa agar lebih baik dalam bersikap dan berakhlakul karimah kepada masyarakat di lingkungan sekolah supaya bisa terhindar dari tindakan bullying. (Aliy Ahmad R. M., 2020)

Penanaman pendidikan agama islam melalui solat berjamaah juga di amalkan oleh wilayah Zaid bin Tsabit (K), Pondok pesantren Nurul Jadid, Paiton, Probolinggo. Penggiatan solat berjamaah sangat aktif dilaksanakan lima waktu yang merupakan kegiatan wajib di wilayah tersebut. Peran pengasuh yang terjun ke lapangan dalam mengontrol kegiataan dan memimpin jamaah solat menjadikan santri lebih giat dalam kegiatan solat berjamaah. Pengurusan dan kepanitian solat berjammah dibentuk demi melancarkan lagi kegiatan tersebut. Sentuhan rohani yang ditausiahkan oleh pemangku sendiri setelah wiridhan secara tidak langsung memberi motivasi kepada santri untuk tetap berproses menjadi lebih baik dari waktu ke waktu. Hal tersebut merupakan salah satu bentuk usaha mencegah sekaligus mengatasi masalah bulliying yang semakin merebak di pesantren.

Pembinaan Pendidikan Agama Islam melalui 'Kajian Tafsir' di pondok pesantren Nurul Quran, Kraksan, Probolinggo yang rutin dilaksanakan setiap malam jumat merupakan cara untuk menguatkan akidah santri. Melalui kegiatan kajian tafsir tersebut, ustad atau muallimat yang bertugas menguraikan penjelasan tafsir Quran 
yang diselangi kata nasehat, dan motivasi supaya santri semakin dekat dengan sang pencipta. Dengan itu, secara tidak langsung karakter santri dididik untuk sentiasa berada dijalan yang tepat yaitu Sirotol Mustakim. (Rodiyah, 2020)

Strategi yang bisa diterapkan oleh guru PAI dalam menangani perilaku bullying siswa di sekolah ialah dengan penanaman nilai-nilai ke-Islaman atau akhlak kepada siswa pada kegiatan belajar mengajar dalam kelas, kemudian menasehati secara langsung jika terdapat santri yang berperilaku tidak baik kepada temannya. Seterusnya strategi dalam menangani masalah bullying santri di pesantren yaitu mengadakan bimbingan konseling di sela-sela waktu pergantian jam pelajaran masuk kelas. Selanjutnya mengadakan bimbingan secara individu di ruang Bimbingan Konseling (BK).

\section{KESIMPULAN DAN SARAN}

\section{Kesimpulan}

Inti dari penelitian diatas dapat disimpulkan bahwa perilaku bullying terjadi tanpa ada maksud yang jelas atau dengan tujuan untuk menganggu korban yang dilakukan secara sengaja. Perilaku bulliying ini tersebut dapat menyakiti korban baik secara fisik maupun psikis sehingga dapat memberikan dampak negatif pada korban. Seperti adanya perasaan tertekan, takut, cemas, sedih dan membuat korban tidak nyaman serta kehilangan motivasi. Kondisi yang dialami korban secara berulang dapat berpengaruh terhadap kepercayaan diri, harga diri dan prestasi akademik. Bulliying merupakan salah satu sikap remaja yang sangat tidak baik yang mana sudah menjadi perbincangan hangat di dunia pendidikan bukan saja di Indonesia namun, juga di dunia internasional. Pencegahan sejak dini harus dilaksanakan supaya hal tersebut tidak semakin merebak.

\section{Saran}

Penelitian selanjutnya diharapkan agar kembali mengangkat isu-isu yang berkaitan dengan bulliying khususnya yang terjadi pesantren dan disarankan kepada peneliti agar dapat memperluas responden penelitian bukan hanya pada pelaku namun juga kepada korban bulliying yang terjadi di kalangan masyarakat dan khususnya kepada anak didik.

\section{DAFTAR PUSTAKA}

Ade Imelda Frimayanti, Imlpementasi Pendidikan Nilai Dalam Pendidikan Agama Islam, Al-Tadzkiyyah: Jurnal Pendidikan Islam, Volume 8 No. Ii, 2017

Ahmad Nashiruddin. (2019). “Fenomena Bullying Di Pondok Pesantren Al-Hikmah Kajen Pati", Jurnal Quality, Vol. 7, No. 2, P.81-99 
Aliy Ahmad, Rosichinmansur, Ach Faisol, Internalisasi Nilai-Nilai Pendidikan Agama Islam Dalam Mencegah Perilaku Bulliying (Studi Kasus Di Mts Nurul Ulum Malang), Vicratina: Jurnal Pendidikan Islam, Vol. 5 No. 1, 2020, Hal.10

Aliy Ahmad, Rosichin Mansur, Internalisasi Nilai-Nilai Pendidikan Agama Islam Dalam Mencegah Perilaku Bullying (Studi Kasus Di Mts Nurul Ulum Malang) Ach Faisol, Vicratina: Volume 5 Nomor 1, 2020, Hal. 11

Aliy Ahmad, Rosichinmansur, Ach Faisol, Internalisasi Nilai-Nilai Pendidikan Agama Islam Dalam Mencegah Perilaku Bulliying (Studi Kasus Di Mts Nurul Ulum Malang), Vicratina: Jurnal Pendidikan Islam, Vol. 5 No. 1, 2020, Hal. 13

Ariobimo Nusantara, Bullying Mengatasi Kekerasan Di Sekolah Dan Lingkungan Sekitar Anak, (Jakarta: Grasindo, 2008), H. 4-5

Athi' Linda Yani, Indah Winarni, Retno Lestari, Eksplorasi Fenomena Korban Bullying Pada Kesehatan Jiwa Remaja Di Pesantren, Jurnal Ilmu Keperawatan, Vol:4, No. 2, 2016.

Eli Wardianti, 2018, Pengaruh Bulliying Terhadap Moralitas Siswa Pada Smp Negeri 1 Darul Hikmah Kabupaten Aceh Jaya. Hal. 4

Eli Wardianti, 2018, Pengaruh Bulliying Terhadap Moralitas Siswa Pada Smp Negeri 1 Darul Hikmah Kabupaten Aceh Jaya. Hal. 14-15

Jamil Salmi, Kekerasan Dan Kapitalisme, (Yogyakarta: Pustaka Pelajar Offset, 2003), H. 31-32.

Madin, 2013, Fenomena Bulliying Dalam Pendidikan, Jurnal Al-Tadrib, Vol. 6 No. 2 Juli- Desember, 2013

Maziyatul Hamidah Religiusitas Dan Perilaku Bullying Pada Santri Di Pondok Pesantren, Psycho Holistic, Vol.2, No. 1, Mei 2020, Hal. 142

Sucipto, Bullying Dan Upaya Meminimalisasikannya (Bullying And Efforts To Minimize), Psikopedagogia, Vol. 1, No. 1, Juni 2012

Yuliana, Peran Pengasuh Dalam Penanganan Bullying Di Pesantren Darul Ihsan Aceh Besar, 2017, Hal. 33

Wijaya, K., \& Syairozi, M. I. (2020). Analisis perpindahan tenaga kerja informal Kabupaten Pasuruan. Jurnal Paradigma Ekonomika, 15(2), 173-182.

Zidni Nuris Yuhbaba, Eksploitasi Perilaku Buliiying Di Pesantren, Jurnal Kesehatan Dr. Soebandi, Vol. 7, No. 1.

Zidni N. Yuhbaba. (2019). “Eksplorasi Perilaku Bullying Di Pesantren". Jurnal Kesehatan Dr.Soebandi, Vol.7, N0.1, P. 63-71 